\title{
MIGRATION AS A FACTOR OF REGIONAL SOCIO-ECONOMIC EFFECTIVENESS (THE CASE OF RUSSIA'S NORTH)
}

\author{
Vera P. Samarina \\ Tatiana P. Skufina \\ Institute of Economic Problems of the Kola Science Centre of the Russian Academy of Sciences, \\ Apatity, Russia.
}

\author{
Aleksandr V. Samarin
}

Belgorod State National Research University, Belgorod, Russia

The features of population settlement in the North of Russia have been highlighted in the
article. The interest and necessity of such research can be explained by the determining role
of the North for Russia's national economy, escalation of various socioeconomic problems in
the related region and progressing depopulation of these underpopulated areas. The article
reveals the major contradictions in the development of Russia's northern territories at the
present stage. This problem has been studied from two viewpoints. Firstly, on the basis of
the authors'own methodology the demographic indicators of Russia's northern territories
were compared with the average ones within the Russian Federation. Secondly, we have
made an attempt to assess how special the management of these northern territories is in

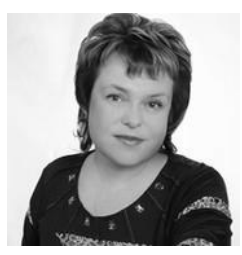

Samarina Vera

is a $\mathrm{PhD}$ (Economics), professor, senior research fellow at the Federal Research Center "Kola Science Center of the Russian Academy of Sciences" (KSC RAS). The area of scientific interests includes issues of regional development, economics of enterprises, industries and industrial complexes, as well as the problems of environmental management. Vera Samarina's research wщn the recognition of the Russian State Scientific Foundation and the Russian Foundation for Basic Research in the form of support by several grants. In 2010 she defended doctoral thesis in the specialty "Economics and management of the national economy (regional economy)" in G. Plekhanov's Russian Economic University (Moscow, Russia). The work was devoted to the improving the methodology for managing of socio-economic development of Russia's problem regions. Vera Samarina is the author of more than 250 scientific papers, 7 textbooks, 6 monographs. She is a member of editorial boards of leading scientific magazines in Russia and Thailand. From 2004 to the present her scientific activity is combined with teaching one. Vera Samarina is a full professor of the Chair of Economics, Management and Organization of production at Stary Oskol Technological Institute (branch) of National Research Technological University "MISiS" (Moscow).

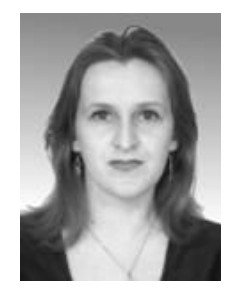

\section{Skufina Tatiana}

is a $\mathrm{PhD}$ (Economics), professor, chief researcher of the Federal Research Center "Kola Science Center of the Russian Academy of Sciences" (KSC RAS), Russia. Her research interests and subjects include regional economics and politics, problems of countries and regions economic growth. A significant number of papers are devoted to the Arctic research. She took an active part in 151 international conferences in Finland, Russia, Austria, Bulgaria, Greece, France, Italy, Thailand, Japan, Switzerland, Ukraine, the United Kingdom and other countries. She is an author of more than 200 scientific papers in national and international journals, 20 monographs, 4 textbooks. Tatiana Skufina is a member of editorial boards of leading scientific magazines in Russia and Thailand. She has directed 16 macroeconomic research projects.

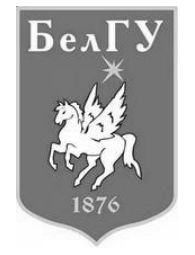

\section{Samarin Alexander}

is a $\mathrm{PhD}$ (Philology), docent and professional translator. The area of scientific interests includes not only economic issues, but problems of translating scientific texts into foreign languages as well. Scientific activity is combined with teaching. Alexander Samarin is an associate professor at the Department of Philology at Belgorod State National Research University (Stary Oskol Branch). Much of his time is devoted to joint research with students. Alexander Samarin and his students took part in numerous philological and economic international conferences in Bulgaria, Lithuania, Japan, USA, Thailand, etc. He is the author of more than 110 scientific papers in national and international journals, 5 textbooks, 2 monographs. 
comparison with other Russian regions. According to the results of our research, directions in migration and population resettlement management have been proposed. These directions will contribute to ensuring higher social and economic efficiency of Russia's northern regions.

Keywords: migration; population settlement; the Arctic zone; Russia's northern regions; frontier territories; demographic indicators; population density; migration balance; population dynamics

\section{Introduction. \\ Contradictions in Development of Russia's Northern Territories at Present Stage}

The relevance of the presented here research has been determined by a persisting contradiction between strengthening geopolitical and economic importance of the northern regions of the Russian Federation and simultaneous aggravation of social and economic losses on these territories which are mostly caused by the strengthening urbanization and accelerated migration processes among the northern population.

At least four contradictions of objective and administrative (subjective) nature form the basis for the local problems. The first one is the objective contradiction between real public processes causing the effect of "northern rise in prices" in economy and social sphere functioning and the need to secure funds for further economic development (by means of Russia's budget replenishment) and social development of Russia's northern regions.

|Most of the qualitative transformations in the social and economic fields of the Russian North took place during the times of the Soviet Union. Some of the local problems were solved thanks to the potential of the socialist socioeconomic regime and the effects from the USSR economy being closed one. The socialist model allowed Soviet authorities concentrate all kinds of huge resources on the solution of strategic tasks. Closed nature of the economy partially levelled the problem of the extremely high fixed costs. At the same time, all positive effects from the development of the North (geopolitical, economic, sectoral, social) belonged only to the state. All of this exerted the most strongest influence on population accommodation.

Industrial development of the northern territories has led to active growth of cities in the region. The pronounced migration movement was observed from central and southern regions to the northern areas. People were attracted by high salaries, easier opportunities to get apartments (quickly and free of charge), to buy cars, furniture, household appliances and to provide themselves with some other material benefits inaccessible as such for the rest of the Soviet Union.

Today state authorities continue to work under the effect of the "northern price rise" for the economy and the social sphere functioning, but without an opportunity to level the price by appropriation of all the effects from the development. Under market economy the state cannot really guarantee high pay as it was back in the Soviet Union. People do not have the opportunity to get state-owned apartments as it used to be. Cars, furniture, expensive household appliances etc. are not deficit anymore. Moreover, people today are able to get good salaries in other regions that are at the same time much more comfortable for accommodation, especially when it comes to weather and climate. This socioeconomic contradiction determines the direction of migration processes. 


\section{MIGRATION AS A FACTOR OF REGIONAL}

At the same time state actions are limited by the second contradiction of nature. This is a contradiction between the declared orientation of the development, the need to fill up the budget and the urgent necessity to innovate the local industries. The harsh reality is that in the foreseeable future already the mineral and raw materials sector will still determine Russia's competitive advantages within the global economy as it is still serving as the largest budget donor, as the basis for economy's modernization etc. This sector is also the most interested consumer of advanced technologies. Finally, this sector determines the directions of nearly all urbanized migration processes. Therefore, it also predetermines the trends in population placement in the northern territories.

On the other hand, foreign experience of the northern regions management should certainly be considered when it comes to territories' arrangement and especially in what concerns balancing economic efficiency with social comfort. However, the scale and complexity of the local socioeconomic problems have no analogues in foreign countries with northern territories. An attempt to consider foreign experience in the northern areas' management while trying to find solutions for the most difficult problems in the development of Russia's northern territories can be actually compared to the attempt to construct a car during while looking at a bicycle. Still, we can single out at least two large groups of "management experiences" in this regard -- works with the purpose of describing actual social and economic processes and those trying to justify concrete managerial decisions taken in the course of the northern territories' development.

On the whole, the theory of the North development from common sense positions would be inconclusive. For example, now there is no theory capable of offering an effective mechanism of social relations for Russia's northern zones. In this regard an important task would be to determine the perspective dynamics of the population placement within the Russian North.

Formulation of this task assumes the application of the cross-disciplinary approach and complexity of the research by default. Innovative character of such research is predetermined by today's tasks of management demanding the development of the objective scientific theory of social and economic development for the North of Russia. The authors of this research project are members of several expert committees and northern territories' economic councils such as the Council for improvement in investment climate in Murmansk region, for example. Thus, they can reasonably claim that there is indeed a demand for such a theory as a strategic concept for the local management. This demand also includes formulation of an absolutely new approach to Russia's northern territories management which would take into account the local specificity.

The Arctic zone of the Russian Federation is isolated from the other northern areas which are expected to be developed as a unified macroobject now. This macroobject is the system of basic zones development formed in each Arctic region. That is, for the first time in the world practice of management of the Arctic territories the development of the Russian Arctic territory will represent, in fact, the unified project of planning through the interconnection of all federal, regional and branch measures of social and economic character at the points of planning, goal setting, financing and implementation. Important place at the same time has to be allocated to the supporting projects aimed at natural increase of population migration in the Arctic region. At the same time, money from such funds has to be turned into real actions and new labor intakes by the industries of all northern territories including the Arctic. 
In this connection, the fundamental goal of our research is to reveal the current state and the prospective directions in population distribution on the North of Russia. In addition, we plan to find out to what extent Russia's northern regions have acquired and kept up the features of the so-called frontier territories.The problem statement predetermines the use of the cross-disciplinary approach due to research complexity.

To achieve this research goal it is necessary to solve a number of the related problems:

- to analyze the distribution of population within the Northern Territories of Russia on the basis of complex indicators;

- $\quad$ to identify the directions and the nature of population migration on the North during different time periods;

- to define and explain the belonging of Russia's northern regions to frontier ones on the basis of the authors' methodology;

- to assess the management features of these territories in comparison with other territories of the Russian Federation.

In our study we proceed from a number of the following hypotheses:

- firstly, Russia's northern regions are poorly populated and continue to lose their population;

- secondly, migration in the regions of the North is voluntary; it has an economic character and its direction has been changing depending on economic and social conditions;

- thirdly, Russia's northern regions have lost the features of frontier territories recently;

- fourthly, Russian authorities do not contribute to the development of these territories as frontier ones due to widespread centralization of management;

- fifthly, problem-solving of the settlement issues on the territories of the North is the key to solving the problems of Russia's socioeconomic development overall.

\section{Methodology}

The notion "population" is to be understood as a set of people living on the Globe (mankind) or within a specific territory such as a continent, a country, region, city, district and so on. Such interpretation can be found in the research works as T. J. Bartik(2009), R. Capello(2009), F. Todtlingand M. Trippl (2004). Using this concept as applied to Russia's Northern territories, it is necessary to decide first on the necessity to add some economic and territorial parameters to the definition of "population". In our particular case, population parameters are limited by the physical borders of the regional system in question.

Population accommodation has been considered by us from two interconnected positions: as a process of people's settling on a certain territory in the course of migration and as a result of this process, that is inhabitants' resettlement by regions and other territorial zones.

In this research the following indicators characterizing population accommodation within Russia's Northern territories were considered:

- area is an area of a territorial subject of the Russian Federation as of 2018 (in square $\mathrm{km})$;

- the Northern zone is the area of the Northern territories of the Russian Federation territorial subjects as of 2018 (in square $\mathrm{km}$ );

- number of cities is the number of settlements having the city status as of 2018; 


\section{MIGRATION AS A FACTOR OF REGIONAL}

- the number/share of urban population to the total number of population residing within a territorial subject of the Russian Federation, the ratio as of 2018 (\%);

- population density is calculated as the ratio between the number of population to the total physical area of a territorial subject of the Russian Federation, as of 2018 (people per 1 square $\mathrm{km}$ );

- the balance of migration is calculated as the difference between the number of people arriving to the territory of a Russian Federation territorial subject and the number of people leaving it; data also as of 2018 (in thousand people).

The following demographic indicators characterizing the population of Russia's northern territories have been investigated in this research:

- population size is the average number of the residing population by Russian Federation subjects. Calculations are available for such year: 1928, 1958, 1978, 19882008 and 2018 (in thousand people);

- gender ratio is calculated as the number of women permanently residing within a territorial entity of the Russian Federation per 1,000 men permanently residing within the same subject of the Russian Federation, as of 2014 (\%);

- average age is calculated as the average arithmetic weighted;

- birth rate is calculated as the number of newly born babies per 1000 of local residents, data as of 2014 (in \%);

- mortality rate is calculated as the number of deaths per 1000 people residing within the territories in question, as of $2014(\%)$;

- natural growth rate is calculated as the difference between the birth rate and the death rate on the same territory, as of 2014 (in \%);

- life expectancy (the average life expectancy at birth) stands for the mortality rate of population; this is the average number of years of the upcoming life of a person permanently residing on the territory of the Russian Federation subject at birth, also as of 2014 (in years).

One of the areas of our research concerns clarifying the question whether Russia's Northern territories are frontier ones.

This question will be studied from the two positions.

First, we will compare the demographic indicators of Russia's Northern territories with average ones in the Federation. Secondly, we will estimate how special and unique is Northern territories' management in comparison with other territories of the Russian Federation.

In our study, we suggest to consider the following demographic characteristics of the frontier territories as the key ones:

- gender ratio - as the number of men exceeding the number of women;

- the average age of population should be lower than in other territories;

- the coefficient of natural increase should be positive;

- balance of migration should be also distinctly positive;

- the nature of migration must be economic and mostly voluntary.

We also assume that the Northern territories will differ because they have smaller number of cities with a large share of urban population and low population density on the rest of the territories. The objects of our study are regions of the Russian Federation, whose territories are fully or partially located in the Far North (that is, beyond the Polar Circle) or equivalent areas. 


\section{Indicators of population settling in the Russian Federation regions, completely or partially located in the North}

First of all, let us estimate the statistical indicators of the population settling within the Russian Federation subjects the territories of which are completely or partially located in the North zone. The research is based on the data compiled and provided by the Federal State Statistics Service of the Russian Federation as of 2018.

As of 2018, the overall area of the Russian Federation territory is $17,125,191 \mathrm{~km}^{2}$. At the same time, the total area of the Russian Federation subjects, commonly referred to as the Russian North, is $782,292 \mathrm{~km}^{2}$, or $45.66 \%$ of the country's territory. The total area of the Russian Federation subjects, partially located within the North is $8989150 \mathrm{~km}^{2}$, or $52.49 \%$ of the country's territory. In total, the area of the Russian Federation subjects, fully or partially on the North, is $98.16 \%$ of the country's territory. The zone of the North itself occupies more than $70 \%$ of the Russian Federation territory. No other country on this planet has such vast northern territories.

At the same time, the share of urban population in the northern territories is usually high. The increased share of urban population has been always predetermined by the industrial character of the North territories' development. Generally speaking, the share urban population in the Russian Federation overall was $74.43 \%$, as of 2018 . In the northern territories it is significantly higher, on average, around $78.66 \%$. The highest rates of urban population always fall on the most industrially developed regions which are Magadan Region (95.89\% living in cities), Khanty-Mansi Autonomous District (92.34\%) and Murmansk Region (92.33\%). There are two exceptions in this regard: the Republic of Tuva (54.04\% of urban population) and the Republic of Sakha (Yakutia) (64.01\% of urban population).

Among the regions only partially located in the North zone the share of urban residents is notable lower. The average value of urban population in these regions is $69.70 \%$. This is even lower than the average indicator for Russia as a whole. The highest rate in this group belongs to the Khabarovsk Territory $(82.13 \%)$. The lowest indicator belongs to the Republic of Altai which has only one city actually, thus, the share of urban population there is $28.65 \%$ only.

\section{Key features of the Northern settlements}

The number of cities in the northern territories overall is quite small. As we can see in Table 1, at present there are 139 urban settlements in the regions, fully located within the boundaries of the North. There are 127 urban settlements in the regions partially located on the North. There are even regions with only one really urban settlement.

For example, the Nenets Autonomous District, which is a fully northern territory with the total area of $177,000 \mathrm{~km}^{2}$, or the Altai Republic partially located on the North, with theterritory of $93,000 \mathrm{~km}^{2}$. Two cities only are located in the Magadan Region while its overall territory is $462,000 \mathrm{~km}^{2}$. The Chukotka Autonomous District $\left(721,000 \mathrm{~km}^{2}\right)$ and Kamchatka Territory $\left(464,000 \mathrm{~km}^{2}\right)$ have only three cities each, despite the fact that their territories are truly enormous! At present, $79 \%$ of all northern cities are small, and they are home to $40 \%$ of all the northerners. 


\section{MIGRATION AS A FACTOR OF REGIONAL}

Table 1 - The selected statistical indicators of the population settling within

Russian North, as of 2018

(Source: Federal State Statistics Service of the Russian Federation)

\begin{tabular}{|c|c|c|c|c|c|c|}
\hline 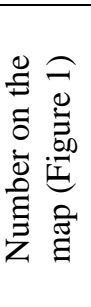 & $\begin{array}{l}\text { Subject of the Russian } \\
\text { Federation }\end{array}$ & $\frac{{ }^{N}}{\frac{E}{8}}$ & 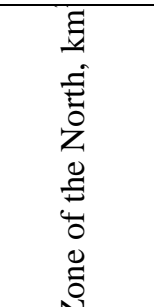 & 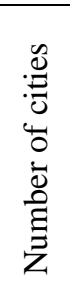 & 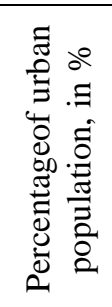 & 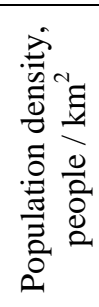 \\
\hline \multicolumn{7}{|c|}{ Subjects of the Russian Federation fully located in the North } \\
\hline 1 & Murmansk Region & 144900 & 144900 & 16 & 92,33 & 5,20 \\
\hline 2 & The Republic of Karelia & 180520 & 172400 & 16 & 80,41 & 3,45 \\
\hline 3 & Arkhangelsk Region & 589913 & 234000 & 32 & 78,00 & 1,96 \\
\hline 4 & $\begin{array}{l}\text { Nenets Autonomous } \\
\text { District }\end{array}$ & 176810 & 176810 & 1 & 72,84 & 0,25 \\
\hline 5 & $\begin{array}{l}\text { The Sakha Republic } \\
\text { (Yakutia) }\end{array}$ & 3103200 & 3103200 & 13 & 64,1 & 0,31 \\
\hline 6 & $\begin{array}{l}\text { Chukotka Autonomous } \\
\text { District }\end{array}$ & 721481 & 721481 & 3 & 70,51 & 0,07 \\
\hline 7 & Kamchatka Territory & 464275 & 464275 & 3 & 78,22 & 0,68 \\
\hline 8 & Sakhalin Region & 87101 & 87101 & 14 & 82,02 & 5,63 \\
\hline 9 & Magadan Region & 462464 & 462464 & 2 & 95,89 & 0,31 \\
\hline 10 & $\begin{array}{l}\text { Yamal-Nenets } \\
\text { Autonomous District }\end{array}$ & 769250 & 769250 & 8 & 83,82 & 0,70 \\
\hline 11 & $\begin{array}{l}\text { Khanty-Mansi } \\
\text { Autonomous District }\end{array}$ & 534800 & 534800 & 16 & 92,34 & 3,09 \\
\hline 12 & The Republic of Tuva & 168604 & 168604 & 5 & 54,04 & 1,91 \\
\hline 13 & The Republic of Komi & 416774 & 416774 & 10 & 78,11 & 2,02 \\
\hline \multicolumn{7}{|c|}{ Subjects of the Russian Federation partially located on the North } \\
\hline 14 & Tomsk Region & 314391 & 259040 & 6 & 72,41 & 3,43 \\
\hline 15 & Khabarovsk Territory & 787633 & 654000 & 7 & 82,13 & 1,69 \\
\hline 16 & Tyumen Region & 1464173 & 47850 & 5 & 80,66 & 2,52 \\
\hline 17 & Krasnoyarsk Territory & 2366797 & 463261 & 23 & 77,39 & 1,22 \\
\hline 18 & Irkutsk Region & 744846 & 475170 & 22 & 78,78 & 3,10 \\
\hline 19 & PrimorskyTerritory & 1913037 & 38450 & 12 & 76,32 & 11,62 \\
\hline 20 & The Republic of Altai & 92903 & 38407 & 1 & 28,65 & 2,35 \\
\hline 21 & $\begin{array}{l}\text { The Republic of } \\
\text { Buryatia }\end{array}$ & 351334 & 186800 & 6 & 59,01 & 2,80 \\
\hline 22 & Zabaikalsky Territory & 431892 & 152110 & 10 & 68,22 & 2,48 \\
\hline 23 & Amur Region & 361908 & 219370 & 10 & 67,37 & 2,21 \\
\hline 24 & Perm Territory & 160236 & 32770 & 25 & 75,80 & 16,3 \\
\hline
\end{tabular}

The key economic feature of the majority of rural settlements within the Northern territories is their non-agricultural functional orientation. These are mostly industrial settlements - builders, miners and drilling workers' reside here, mostly on the rotational basis which we have described above. There are also settlements that were founded and developed in the course of the military-industrial complex development: the so-called military towns, frontier posts, settlements for service personnel etc. 
Another peculiarity of the local population resettlementis the existence of a specific group of closed settlements. As a rule, these are the settlements of the people directly involved in nuclear weapons production, working at secret military bases, weapon testing ranges and the like. In Murmansk region there are 5 such settlements, 1 in Arkhangelsk Region, 1 in Tomsk Region, 1in Amur Region, 5 in Krasnoyarsk Territory, 2 in Kamchatka Territory, 2 in Zabaikalsky Territory and 3 in PrimorskyTerritory.

The monofunctionality of small towns and settlements of the North often predetermineshigh unemployment rate in them. Population's purchasing power is low, the majority of the local inhabitantsdo not have any opportunity (partially due to the closed nature of such military or former military settlements) to move to more favorable areas for life. In addition to that, the Northern regions are located above the isoline of sustainable crop cultivation and thus, are unsuitable for farming. Thus, as there are zero opportunities for farming(which is quite widespread among unemployed population in rural parts of other regions of Russia) migration inevitably takes place, people move to large cities in their search for work.

The most common negative feature of all the Northern regions is low diversification of economic activities. Many northern municipalities are the so-called monotowns. People who have been fired (no matter what's the reason for firing) from the core enterprise of a town, simply do not have a chance to find alternative employment opportunities. Such a situation has been gradually causing systemic unemployment which, in its turn, leads to overall decrease in all business and other economic activities within the whole region. Moreover, the overall social and economic balance of the Northern territoriesoften depends ontax revenues from only a few huge enterprises. Thus, the problems of monotownquickly become the problems for the whole region (Bartik, 2009; Rodrik, 2008; Tötzer, Gigler, 2005; Trippl, Otto, 2009). In what concerns social life and population welfare, the problem of mono-towns leads to overall decrease in the standards of living and also to gradually rising social instability.

\section{Population dynamics of Russia's Northern territories and their balance of migration}

Let us consider the population dynamics of the Russian northern territories during the period since 1929 till 2018. The results of our analysis are presented in Table 2.

The table above clearly shows all changes in the local population dynamics. The resettlement rate of the population on the Russian North has been increasing since the 1930s. The causes for migration were mainly related to industries' development. At the same time, people were either moved by force in the course of mass deportations (this was forced migration), or were attracted by various benefits (raised wages, lowered retirement age, quick provision with state-owned accommodation, vacation packages for all family members' during the summer holidays etc.). The latter was voluntary migration.

Mass forced migration has practically ceased during the second half of the 1960s. Voluntary migration has been gradually exceeding forced one. The population of the northern regions was constantly growing. As data in Table 2 shows, the largest population numbers in all the regions in question was observed in 1989. The local population boom continued until the early 1990s when the Soviet Union collapsed. 


\section{MIGRATION AS A FACTOR OF REGIONAL}

Table 2. Population of Russia's northern territories, 1929 to 2018

(Source: Federal State Statistics Service of the Russian Federation)

\begin{tabular}{|c|c|c|c|c|c|c|c|}
\hline \multirow[b]{2}{*}{ Subjects of the Russian Federation } & \multicolumn{6}{|c|}{ Population, in thousand people } & \multirow{2}{*}{$\begin{array}{c}\text { Migration } \\
\text { balance } * * \\
\text { thousand } \\
\text { people }\end{array}$} \\
\hline & 1929 & 1959 & 1979 & 1989 & 2009 & 2018 & \\
\hline \multicolumn{8}{|c|}{ Subjects of the Russian Federation fully located in the North zone } \\
\hline Murmansk Region & 24 & 568 & 965 & 1147 & 886 & 754 & $-3,5$ \\
\hline The Republic of Karelia & 247 & 651 & 736 & 791 & 690 & 622 & $+0,1$ \\
\hline Arkhangelsk Region & 432 & 1230 & 1420 & 1555 & 1272 & 1155 & $-5,2$ \\
\hline Nenets Autonomous District & 15 & 37 & 47 & 55 & 42 & 44 & $+0,1$ \\
\hline The Sakha Republic (Yakutia) & 280 & 487 & 820 & 1072 & 951 & 964 & $+2,2$ \\
\hline Chukotka Autonomous District & 14 & 47 & 133 & 157 & 51 & 49 & $-0,2$ \\
\hline Kamchatka Territory & 28 & 221 & 378 & 466 & 334 & 316 & $-2,7$ \\
\hline Sakhalin Region & 17 & 648 & 655 & 710 & 519 & 419 & $-4,0$ \\
\hline Magadan Region & 20 & 189 & 333 & 386 & 183 & 144 & $-3,2$ \\
\hline Yamal-Nenets Autonomous District & 32 & 62 & 158 & 482 & 543 & 539 & $+0,4$ \\
\hline Khanty-Mansi Autonomous District & 23 & 123 & 569 & 1268 & 1433 & 1655 & $+8,9$ \\
\hline The Republic of Tuva & $\mathrm{n} / \mathrm{a}^{*}$ & 172 & 267 & 309 & 306 & 322 & $-0,7$ \\
\hline The Republic of Komi & $\mathrm{n} / \mathrm{a}$ & 815 & 1119 & 1261 & 1006 & 841 & $-6,0$ \\
\hline \multicolumn{8}{|c|}{\begin{tabular}{|c|} 
Subjects of the Russian Federation partially located in the North zone \\
\end{tabular}} \\
\hline Tomsk Region & $\mathrm{n} / \mathrm{a}$ & 747 & 866 & 1001 & 1039 & 1078 & $+0,8$ \\
\hline Khabarovsk Territory & 187 & 979 & 1376 & 1609 & 1437 & 1329 & $+0,7$ \\
\hline Tyumen Region & $\mathrm{n} / \mathrm{a}$ & 1092 & 1887 & 3080 & 3400 & 3692 & $+10,5$ \\
\hline Krasnoyarsk Territory & $\mathrm{n} / \mathrm{a}$ & 2160 & 2637 & 2948 & 2908 & 2876 & $+3,2$ \\
\hline Irkutsk Region & $\mathrm{n} / \mathrm{a}$ & 1977 & 2559 & 2831 & 2446 & 2404 & $-5,0$ \\
\hline PrimorskyTerritory & 724 & 1381 & 1978 & 2258 & 2071 & 1933 & $-5,5$ \\
\hline The Republic of Altai & 101 & 157 & 172 & 192 & 203 & 218 & $+0,1$ \\
\hline The Republic of Buryatia & 391 & 673 & 900 & 1041 & 981 & 984 & $+1,5$ \\
\hline Zabaikalsky Territory & $\mathrm{n} / \mathrm{a}$ & 990 & 1165 & 1301 & 1083 & 1073 & $-0,2$ \\
\hline Amur Region & 509 & 718 & 937 & 1058 & 895 & 798 & $-2,8$ \\
\hline Perm Territory & 2321 & 2992 & 3009 & 3095 & 2718 & 2623 & $+0,1$ \\
\hline
\end{tabular}

* n/a - no official statistics available

** as of 2018

Straight after the Soviet Union collapse, the population of the North began to decline sharply. Under the conditions of the market economy, the state has not been able anymore to guarantee previous "northern privileges" and higher salaries. Many enterprises of the North were closed as such, as they quickly became unable to withstand competition with foreign and Russian enterprises that demonstrated to be having lower costs. High costs of the northern enterprises were associated not only with specific climatic and geographical conditions, but also with the need to pay higher wages to local employees. Thus, when local people lost their highly paid jobs and other benefits, they began to move massively to other Russia's regions in search for more comfortable living conditions. Table 2 also shows that during these 20 years, 1989 to 2009, population in all these regions has dramatically decreased. This was economic and voluntary emigration.

This situation persisted until recently, actually In the recent years, the population has begun to return to some of the northern territories. Thus, in 2018, as compared with 2009, the population of the Nenets Autonomous District, the Republic of Sakha (Yakutia), and Khanty-Mansiysk Autonomous District has increased. In 2018 the balance of migration in 
these regions was positive. All these regions are oil producing. Today the population is attracted with high wages paid by oil-producing enterprises. The positive balance of migration and its voluntary nature are predetermined by purely economic motivations. Therefore, it becomes possible to classify the regions in question as frontier ones. The situation is not so good in the remaining northern regions though, the balance of migration in most of them, as of 2018, was still negative.

The situation in the regions whose territories are partially located on the North is similarly ambiguous. So, in 2018 in comparison with 2009 the population of oil-producing Tomsk and Tyumen regions has increased.

The balance of migration in these regions remained positive in 2018. The population of the Republic of Altai and the Republic of Buryatia also increased. These regions are rich in minerals but they have no oil, they are subsidized and traditionally underdeveloped socioeconomically.

In other regions population numbers have not reached the 2009 values till now. However, in 2018 the balance of migration in most the regions in question was positive and this means that he population is gradually returning to the northern territories. The key reason for such migration is very much the same - the economic one. And once again, this is voluntary migration.

As of 2018, the population of the Russian Federation was 146.8 mln.people. In the northern territories there lived 7.824 .000 people, or $5.33 \%$ of Russia's total population. There were 19.008 people, or $12.94 \%$ of Russia's entire population on the territories partially located on the North. Thus altogether, 26.832 .000 people, or $18.27 \%$ of Russia's total population are living on the territories fully or partially located on the North. Comparing these population numbers with the actual size of the territories of the Russian Federation, fully or partly located on the North $(98.16 \%)$, we can see that barely a minimum of population lives on these vast northern territories.

\section{Evaluation of the northern regions of the Russian Federation as frontier territories according to demographic indicators}

Table 3 presents the selected demographic indicators of the Russian Federation subjects whose territories are fully or partially located on the North. According to these 2014 data, we can determine whether the regions in question can be referred to as frontier territories in accordance with their demographic characteristics.

Let us analyze these table data in detail. As of 2014 in Russia there were 1140 women for 1000 men on average. In Russia's northern regions the situation with gender ratio is nearly complete opposite. On the northern territories it is on average $101.4 \%$, or in simple terms, there are 1000 men per 1014 women. The highest rates are in the Republic of Karelia (119. 5\%) and in the Arkhangelsk region (114.2\%). This ratio exceeds Russia's national mean value. However, these regions are exceptions in many regards, including gender ratio. In 7 regions out of 13 fully located in the North zone there are fewer women than men.

Gender ratio on the territories, partially located in the North zone is $103,8 \%$, that is, 1000 men for 1038 women. This is also lower than in Russia on average. Thus, Russia's territories, fully or partly located on the North, in accordance with the gender ratio can be referred to as frontier territories.

Now let's turn to the indicator of average age. As of 2014, the average age in the Russian Federation was 37.7 years. On the northern territories it was lower: the average age 


\section{MIGRATION AS A FACTOR OF REGIONAL}

here was 34.9 years. The "youngest" inhabitants are currently living in the Nenets Autonomous District (the average age being 31.5), the Yamalo-Nenets Autonomous District (the average age being 28.7), Khanty-Mansi Autonomous District (31.2) and The Republic of Tuva (29.1). These regions are the same ones that have increased their population in the recent years and have the most positive balance of migration. The average age of population on the territories, partially located in the North zone is 37.4 years old and it practically does not differ from the average age in the Russian Federation as a whole. The youngest in this group are the Republic of Altai (the average age of 34.8 years old) and the Republic of Buryatia (35.0 years). In other words, the same regions have increased their population in recent years and have positive balance of migration. Thus, Russian territories fully located in the North zone can be considered to be frontier territories by the parameter of the average age.

Table 3. Selected demographic indicators of the Russian Federation subjects fully or partially located on the North, as of 2014

(Source: Federal State Statistics Service of the Russian Federation)

\begin{tabular}{|c|c|c|c|c|c|c|}
\hline Subject of the Russian Federation & 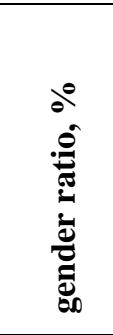 & 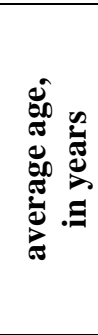 & 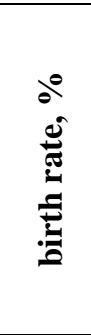 & 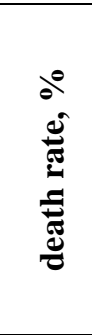 & 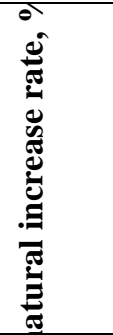 & 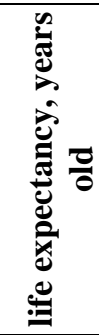 \\
\hline \multicolumn{7}{|c|}{ Subjects of the Russian Federation fully located in the North zone } \\
\hline Murmansk region & 105,1 & 37,6 & 11,8 & 11,4 & $+0,4$ & 70,46 \\
\hline The Republic of Karelia & 119,5 & 39,6 & 12,4 & 14,6 & $-2,2$ & 69,2 \\
\hline Arkhangelsk Region & 114,2 & 37,0 & 12,6 & 13,2 & $-0,6$ & 70,16 \\
\hline Nenets Autonomous District & 99,2 & 31,5 & 16,6 & 8,9 & $+7,7$ & 65,76 \\
\hline The Sakha Republic (Yakutia) & 103,1 & 34,1 & 16,9 & 8,6 & $+8,3$ & 69,13 \\
\hline Chukotka Autonomous District & 97,8 & 34,0 & 13,3 & 10,7 & $+2,6$ & 62,11 \\
\hline Kamchatka Territory & 97,6 & 40,0 & 13,2 & 11,5 & $+1,7$ & 67,98 \\
\hline Sakhalin Oblast & 99,9 & 38,1 & 13,6 & 13,0 & $+0,6$ & 67,70 \\
\hline Magadan Region & 86,4 & 37,2 & 12,2 & 11,9 & $+0,3$ & 67,12 \\
\hline Yamal-Nenets Autonomous District & 90,9 & 28,7 & 16,4 & 5,1 & $+11,3$ & 71,23 \\
\hline Khanty-Mansi Autonomous District & 94,7 & 32,1 & 17,3 & 6,4 & $+10,9$ & 72,23 \\
\hline The Republic of Tuva & 107,9 & 29,1 & 25,3 & 10,9 & $+14,4$ & 61,79 \\
\hline The Republic of Komi & 102,2 & 34,5 & 14,1 & 12,2 & $+1,9$ & 69,27 \\
\hline \multicolumn{7}{|c|}{ Subjects of the Russian Federation partially located in the North zone } \\
\hline Tomsk Oblast & 108,6 & 38,0 & 13,7 & 11,8 & $+1,9$ & 70,33 \\
\hline Khabarovsk Territory & 95,4 & 39,7 & 14,0 & 13,3 & $+0,7$ & 67,92 \\
\hline Tyumen Region & 105,1 & 37,2 & 17,2 & 8,3 & $+8,9$ & 71,35 \\
\hline Krasnoyarsk Territory & 105,1 & 37,7 & 14,5 & 12,7 & $+1,8$ & 72,29 \\
\hline Irkutsk Region & 105,4 & 37,3 & 15,4 & 13,8 & $+1,6$ & 66,72 \\
\hline PrimorskyTerritory & 988 & 41,7 & 12,8 & 13,4 & $-0,6$ & 68,19 \\
\hline The Republic of Altai & 106,6 & 34,8 & 20,9 & 11,2 & $+9,7$ & 67,34 \\
\hline The Republic of Buryatia & 106,5 & 35,0 & 17,5 & 11,5 & 6,0 & 67,67 \\
\hline Zabaikalsky Territory & 103,4 & 35,5 & 16,0 & 12,4 & 3,4 & 67,11 \\
\hline Amur Region & 100,8 & 36,2 & 13,8 & 13,9 & $-0,1$ & 66,38 \\
\hline Perm Territory & 106,2 & 38,8 & 14,8 & 14,0 & $+0,8$ & 67,82 \\
\hline
\end{tabular}


In 2018 , the birth rate in Russia as a whole was $13.3 \%$, or in other words, 13.3 babies per 1,000 residents. On the northern territories, the fertility rate fluctuated from about $11.8 \%$ in Murmansk region to $25.3 \%$ in the Republic of Tuva. The same indicators range is noted on the territories, partially located in the northern zone: from $12.8 \%$ in the Primorsky territory to $20.9 \%$ in the Altai Republic.

The averaged death rate in Russia is $13.0 \%$, that is, 13.0 per 1000 residents. On the northern territories the mortality rate varied considerably: from 5.1\% in the Yamalo-Nenets Autonomous District to $14.6 \%$ in the Republic of Karelia. The same indicators range is noted on the territories, partially located in the North zone: from $8.3 \%$ in the Tyumen region to $14.0 \%$ in the Perm territory.

Positive natural growth is a feature of the regions fully or partially located in the northern zone since the number of births in most of these regions exceeds the number of deaths. The exceptions among these northern territories are the Republic of Karelia and the Arkhangelsk region. The exceptions among the regions, partially located in the North zone are Primorsky Territory and Amur oblast.

Russia's averaged rate of natural increase was $0.3 \%$. In most of the territories, fully or partly located in the Northern zone, this figure is much higher. Particularly high values were noted in the Yamalo-Nenets Autonomous District (the natural growth rate there is 11.3\%), the Khanty-Mansi Autonomous District (the rate of natural increase is 10.9\%) and the Republic of Tuva (the natural growth rate is $14.4 \%$ ). These regions have positive migration balance.

Thus, the increased growth of population in the North regions during the recent years has been ensured not only by migration, but also because the birth rate was over the death rate (Samarina et al., 2018). Moreover, by the parameter of the natural increase the northern regions can be referred to frontier territories.

\section{Peculiarities of Russia's Northern Territories' Management}

The major peculiarities in management of Russia's northern territories should be considered at different levels, each level having its own geopolitical, macroeconomic, mineral and social factors.

\section{Global level.}

This group of factors concerns mostly the uneven distribution of natural resources, the depletion of reserves, the reduction of opportunities for discovering new deposits under more favorable conditions and, at the same time, the growing demand of the world economy for minerals. All of the above inevitably strengthens the global struggle for resources. The pressure of this reason is so hard that it has already led to some territorial losses in Russian zone of the North. In particular, according to the agreement as of 2010 concerning the delimitation of the "gray zone" in the Barents Sea with Norway, Russia lost some of the territories rich in hydrocarbon raw materials and other highly important resources. Territorial losses in his zone automatically mean huge geopolitical and economic losses for the whole Russian Federation.

Economic losses are immediately visible, direct losses in this situation, while indirect losses are important as well. This recent division has also strengthened Norway's position regionwide and globalwide. Norway, in particular, is Russia's main competitor at European oil and gas market. And in this context, the largest Russian Stockman project was curtailed 


\section{MIGRATION AS A FACTOR OF REGIONAL}

as there were difficulties with gaining access to Western offshore mining technologies etc.

The social aspect of management is also determined not only by the regional and sectoral levels, but also by the global one (Samarina et al., 2018).

Natural-climatic and geographical features make the North zone the least attractive for life. Such situation is not limited to Russia only. A number of foreign researchers of the North mention this fact as well, for example, M. Berman and L. Howe (2012).

\section{Macroeconomic level.}

The change in the protectionist policy towards the North has led to a massive loss in local socioeconomic indicators. It is in contradiction with the economic requirements for these territories and it entails irreplaceable infrastructural losses. This also contradicts the foreign countries' practice in northern territories' management and creates the geopolitical problem of the so-called "empty space".

At the same time, there is an obvious urgent necessity to specify in greatest possible detail the multifold tasks the federal government is facing today while shaping a new management approach - a spatial one. This approach stems from the initial idea of singling out a macroobject - Russia's Arctic zone among Russian northern territories. The authors of this idea/project are the members of the working groups which had been formed to analyze numerous versions of the draft federal law "On the Development of the Arctic Zone of the Russian Federation" (hereinafter - the Draft Law).

This law was planned as some sort of an "Arctic Code" for better, more efficient management of a wide range of development problems within Russian northern territories. However, on January 31, 2017 one more version of this legal act was rejected and sent for another revision in order to modify the content with the focus primarily being on the mechanism supporting zones formation.

\section{Regional level.}

Living on the North, on the one hand, means low level of comfort and increased risks for population. On the other hand, this means regional authorities are expected to ensure vital processes' implementation for all inhabitants of the northern territories. At the same time, these local authorities should not only create and maintain infrastructure in the northern cities and other settlements. It is much more important for them to ensure overall socioeconomic development of the northern territories. Increasing the rate of socioeconomic development on the northern territories is also mentioned as the goal of the State Program "Socioeconomic development of the Arctic zone of the Russian Federation" which was presented in its newest edition in 2017 (Socio-economic development ..., 2017).

The regions are expected to be first of all responsible for achieving the targets of this program. At the same time, as of today, none of the northern regions is actually able to solve the local problems on their own. The capacity of the problem solving is directly related to the investment mechanisms available within Russian northern territories. This first of all means the capacity to launch and maintain large sectoral projects (the so-called "anchor projects"). The latter are usually associated with mining specialization of the Russia's North. Implementation of such anchor projects can be regarded as a stabilizing factor ensuring longterm development of the northern regions. 
From the position of the northern regions, ensuring socioeconomic development means finding new opportunities to participate in the "anchor projects" and develop, on their basis, a network of smaller ("not anchored") projects.

The most difficult task the government is facing in this regard is to generate a sufficient number of such projects, taking into account the effectiveness of state-owned and non-state companies' activities included into these projects under market conditions.

\section{Conclusion}

Currently, in the North zone, large areas remain uninhabited: population density in 6 regions out of 13 , fully located in the North, is less than 1 per square $\mathrm{km}$. Oil-producing regions are the most economically developed among the regions of the North. The same regions are also the most attractive ones for population.

The positive balance of migration and its voluntary nature, caused by economic reasons, makes it possible to classify the allocated regions as developing ones. The situation is not so good in the remaining northern regions, the balance of migration in most of them was still negative (as of 2018). Thus, the first hypothesis, that Russia's northern territories are poorly populated and continue to lose their population proves to be correct for most of the regions in question.

It is obvious that population settlement is largely influenced by the indicators of social and economic development. A region developed socially and economically is nearly always attractive for incoming migrants. But as soon as economic recession begins and population starts to lose previously high wages and social preferences, population outflow takes its place. Thus, the second hypothesis that migration in the northern regions is mostly voluntary has economic character and that its direction changes depending on economic and social conditions, turns out to be also correct.

We have also found that according to demographic indicators a fair number of the northern regions can be referred to as frontier territories. According to the gender ratio indicators, there is an excessive number of men over women; the average age of the northern population is "younger" as compared to other Russian territories; the natural increase coefficient is positive; the balance of migration is positive as well; finally, the key migration reason is economic one while migration itself has voluntary nature. At the same time, public management of the northern areas is very much centralized. Therefore, from the viewpoint of management features, Russia's northern territories cannot be considered frontier ones. Therefore, our third hypothesis, that Russian northern regions have lost the features of frontier territories has been partially confirmed.

The federal management center of the Russian Federation is trying to adapt the regions located on the North to management typical of frontier territories. The authorities are trying to introduce special development mechanisms, increase the share of innovative projects in entrepreneurship and attract more passionate individuals who can truly influence the development of the northern territories. Our fourth hypothesis that Russian authorities do not contribute to development of the northern territories as frontier ones because of the widespread centralization has not been confirmed.

In conclusion, it is necessary to note that the importance of the northern territories in the near future will only grow. For example, the consulting company "Rustad Energy" forecasts that by 2020 the territories of the North will own 3\% of the world hydrocarbon production, and by 2035 this share might grow up to $9 \%$. Thus, intensive development of the 


\section{MIGRATION AS A FACTOR OF REGIONAL}

northern territories is the key trend, at least for the foreseeable future. Territories on the North at present and in the foreseeable future are and will be the resource base of the whole Russian economy. And this fact confirms our fifth hypothesis that the solution of the problems with the northern territories' settlement is the key to boosting Russia's development overall.

Obviously, further population migration in the direction from the northern territories undermines not only economic potential of Russia, but also creates problems on the level of geopolitical security. We should note here that in other circumpolar countries, the state administration seeks to stimulate and support the inflow of people to sparsely populated northern areas due to the fact that empty areas constitute a zone of various potential risks. To solve this problem, the territories of the North need to be not only economically developing but inhabited as well. Otherwise, Russia can lose both its labor resources on the North, and territories rich in minerals and other vitally important resources.

\section{References:}

Bartik, T. J. (2009). The Revitalization of Older Industrial Cities: A Review Essay of Retooling for Growth. Growth and Change, 40 (1), 1-29.

Berman, M.\&Howe, L. (2012) Remoteness, Transportation Infrastructure, and Urban-Rural Population Movements in the Arctic Proc. Int. Conf. Urbanisation of the Arctic, Nuuk, Greenland, August 2012. Stockholm: Nordregio, 108-122.

Capello, R. (2009). Indivisibilities, Synergy and Proximity: The Need for an Integrated Approach to Agglomeration Economies. Tijdschrift voorEconomische en Sociale Geographie (TESG), 100 (2), 145-159.

Howe, E. L., Huskey, L. \& Berman, M. D. (2014). Migration in Arctic Alaska: Empirical Evidence of the Stepping Stones Hypothesis. Migration Studies, 2 (1), 97-123.

Rodrik, D. (2008). Industrial policy: don't ask why, ask how. Middle East Development Journal, 8, 129.

Samarina, V. P., Skufina, T. P., Samarin, A. V. \& Baranov, S. V. (2016).Some problems of antirecessionary public management in Russia at present. Management of Systems of SocioEconomic and Legal Relations in Modern Conditions of Development of Education and Society, $6(6 S)$, 38-44.

Samarina, V. P., Skufina, T. P. \& Samarin, A. V. (2018b) Russia's North Regions as Frontier Territories: Demographic Indicators and Management Features. European Research Studies Journal, V. XXI (3), 705-716.

Samarina, V., Skufina, T., Samarin, A. \& Ushakov, D. (2018). Alternative Energy Sources: Opportunities, Experience and Prospects of the Russian Regions in the Context of Global Trends. International Journal of Energy Economics and Policy, 8(2), 140-147.

Socio-economic development of the Arctic zone of the Russian Federation: Decree of the Government of the Russian Federation, as of April 21, 2014, № 366.Accessible from: http://docs.cntd.ru/document/499091750.

Todtling, F. \& Trippl, M. (2004). Like Phoenix from the Ashes? The Renewal of Clusters in Old Industrial Areas. Urban Studies, 41 (5/6), 1175-1195.

Tötzer, T. \& Gigler, U. (2005). Managing urban dynamics in old industrial cities: Lessons learned on revitalising inner-city industrial sites in six European case studies. Amsterdam: 45th Congress of the European Regional Science Association "Land Use and Water Management in a Sustainable Network Society".

Trippl, M. \& Otto A. (2009). How to turn the fate of old industrial areas: a comparison of clusterbased renewal processes in Styria and the Saarland. Environment and Planning, 41, 1217-1233. 
Federal State Statistics Service of the Russian Federation. Accessible from: http://www.gks.ru/wps/wcm/connect/rosstat_main/rosstat/en/main/

Paper submitted

Paper accepted for publishing

Paper published online
19 August 2019

11 October 2019

05 February 2020 